\title{
LANGUAGE LEARNING STRATEGY AND STUDENTS' WRITING SKILL ACHIEVEMENT: A CORRELATIONAL RESEARCH
}

\author{
Fitri Nurdianingsih \\ English Education Department, Faculty of Languages and Arts Education, IKIP PGRI Bojonegoro \\ E-mail: fitrinurdianingsih12@gmail.com
}

APA Citation: Nurdianingsih, F. (2018). Language learning strategy and students' writing skill achievement: A correlational research. Indonesian EFL Journal, 4(2), 23-31. doi: 10.25134/ieflj.v4i2.1372.

Received: 16-03-2018

Accepted: $21-05-2018$

Published: 01-07-2018

\begin{abstract}
Since writing is fundamental in learning to think and express one's thoughts in ways that reach others, the ability to use language coherently and powerfully and to wrtite in ways that connect with others across cultural boundaries and within communities is essential to active citizenship and to success in almost any profession. The problem of the study was to know whether or not there was a significant correlation between students' learning strategy and their writing skill achievement of the second semester students at IKIP PGRI Bojonegoro. This research was a correlational research. The instruments used in this research were writing test and learning strategy questionnnaire. Then, the correlation of the data was calculated by using Pearson Product Moment Formula. The result showed that there is a correlation between students' learning strategy and their writing skill achievement of the second semester students at English Education Department of IKIP PGRI Bojonegoro in academic year 2016/2017.
\end{abstract}

Keywords: Learning strategy; writing skill; achievement; correlational research.

\section{INTRODUCTION}

Writing is about expressing our ideas into sentence or paragraph. It needs ability to express those ideas. Writing is one of the important and productive skills. Harmer (2007, p. 112) says that writing gives the students more thinking time than they get when they attempt spontaneous conversation. Writing becomes important because of some reasons. Raimes (1983, p. 3) states that writing helps the students to learn since it reinforces grammatical structures, idioms, and vocabulary that the teachers have been teaching. Besides, when the students write, they also have a chance to be adventurous with the language, to go beyond what they have just learned to say, to take risks. The next is that when they write, they necessarily become very involved with the new language, the effort to express ideas and the constant use of eye, hand and brain is a unique way to reinforce learning. Writing needs specialized skills that include the ability to express the writer's opinions or thoughts clearly and efficiently.
These abilities can be achieved only if a learner masters some techniques of writing such as how to obtain ideas about what s/he will write, how to express them in a sequence of sentences, how to organize them chronologically and coherently, and how to review and then to revise the composition untuil the writing is well-built (Ratnasari, 2004).

Writing is considered as a demanding skill especially for learners of a second or foreign language (Daud \& Kasim, 2007). It is a demanding skill because the learners have to think in their language then translate their thought or ideas into English. Writing is an important component of both academic and professional success (Powell, 2009). Meanwhile, the process of becoming a successful writer is a complex, long and arduous undertaking (NAEP, 2011) taht requires writers to coordinate a number of cognitive and knowledge skills. These skills include discourse awareness, linguistic 
abilities, goal setting, sociocultural knowledge, and memory management strategies (Kellog \& Whiteford, 2009).

In developing writing as a communicative skill, students should constantly be made aware that particular topics in writing fit particular situations and conform to particular conventions. Conventionally, legal writings use long sentences, formal language and precise definitions to avoid ambiguity and misinterpretations. In the context of physical sciences, writing is characterized by short sentences and short forms or symbolic signs. The role of the language teacher, therefore, is to teach his students to master not only the language skills but also to master the standard language which is free from grammatical errors. The term standard means the language which is standardized and accepted for use in formal communication.

Troyka (1987, p. 2) argues the significances of having writing. First, writing is a way of thinking and learning. Writing gives us unique opportunities to explore ideas and information. By writing, we care to subjects well and make them our own. Thus writing helps us learn and gain authority over knowledge. Second, writing is a way of discovering. The act of writing allows us to make unexpected connection among ideas and language. As we write, thoughts emerge and interconnect in ways unavailable until the physical act of writing began. Third, writing creates reading, visible record of our ideas for other people to read and think over. Writing is a powerful means of communication due to the fact that readings inform and shape human thought. Fourth, writing ability is needed by educated people, our skill of writing is often considered to reflect our level of education, and college work demands that we write many different types of assignments. Most jobs in todays, technological society require writing skill for preparing documents ranging from letters and memos to formal reports. Indeed, throughout our life, our writing will reveal our ability to think clearly and use language to express ideas.

According to Nation (2009, p. 113), writing is an activity that can usefully be prepared for by work in the other skills of listening, speaking and reading. It also significant to make sure that writing can reflect the students' perform in their daily lives. Writing is a complex process of an activity that allows one in transforming thoughts, constructing ideas, discovering meaning and organizing them into sentences and paragraphs which focuses on content firts using the appropriate language. Writing as a skill involves a number of complex rhetorical and linguistic operations which must be taught.the act of writing is deprived of an immediate context of communication. thus, for effective writing, the writer has to use a large number of formal features in order to help his or her readers infer the intended meaning. Failure to use these features correctly causes vagueness, ellipsis and ambiguity in some writings.

Furthermore, writing is the use of graphic symbols arranged according to a certain conventions to form words and sentences (Byrne, 1997, p. 1). He also clarifies that writing is not merelythe act of arranging graphyc symbols. Writing is transforming thought into language, it means that the writer needs to think about the content of writing first and then construct the ideas using appropriate language. Writing involves spelling correctly, forming letter correctly, punctuating correctly and using paragraphs correctly. Writing skill can be defined as a skill to communicate all ideas or imaginations into form of structured pattern, so that the readers may understand what writers mean in their writing. The successful of writing involves some criteria, they are mastering the mechanics of letter formation, using grammatical system to convey one's intended meaning, organizing content at the level of the paragraph, obeying conventions of spelling and punctuation, and selecting an appropriate style for one's audience.

There ara five aspect of writing from Hughes (1996, p. 91), namely:

a. Grammar, that is an element of writing which deals with a set of rules to construct sentences that make sense and acceptable in English

b. Vocabulary, it deals with a list of words and their meanings 
c. Mechanics, that is convention in writing, which is related to punctuation, spelling, and capitalization

d. Fluency, which refers to the ease and the style of the composition

e. Form or organization that is the logical sequence and cohesion or the flow of the ideas being put into written language to make unified contribution to the whole paragraph. It is commonly called as generic structure.

Writing in EFL classes is difficult for both teachers and students because there are many aspects to deal with. Raimes (1983) mentions those aspects are syntax, content, the writer's process, audience, purpose, word choice, organization, mechanics and grammar. Byrne (1993) mentions three aspects which make writing difficult. The first is the phychological problem. Writing is a solitary activity. The teachers cannot get direct feedback like in speaking activity. The second is linguistic problem. The writers have to ensure that the choice of words, sentence structure, and other cohesive devices are correct for conveying their message. The last is the cognitive problem. Writing is learned through a process of instruction. It is not a natural process like speaking. Both Raimes and Byrne basically have the same idea, but Raimes does nt classify the problem. Audience and purpose of writing is included in Byrne's psychological problem. Byrne's linguistic problem covered syntax, word choice, mechanics and grammar. Meanwhile, Raime's writer process, organization and content are covered in Byrne cognitive problem.

Learning is a process indicated by people's change. The change is the result of the learning process which can be seen in the gained of knowledge, comprehension, attitude, behavior, skill, habt, and other aspects stated in the individuals who want to learn. Learning begins at birth and ends at death. People learn under a wide range of conditions and circumstances. We learn more and less continuously everywhere. There are some kinds of learning, such as language learning. Language learning is an integrated and long process. Sometimes, mistakes appear in language learning process and it is normal for language learners. Besides, language learners must be active in teaching learning process so the goal of learning can be achieved.

Learning writing is the most avoided subject among other skill subjects in English. In fact, learning writing has been proven to give advantages to the students in the terms of enhancing their languagr learning strategies which has currently become a great concern of many experts propose that by interconnecting reading and writing, students will develop a great deal in their literacy skill. Some researchers, as reported by the Major English Language Arts Professional Organization (Yale, 2010), have found that when students read extensively, they become better writers. At the same time, as Yale (2010) says, practice in writing helps students build their reading skills, in the sense that practice in the process of writing their own texts helps them analyze the pieces that they read. As a result, they can apply their knowledge about the ways to use particular language (word choice, combining words into logical and grammatical sentence structures, appropriate registers, etc) to better understand a professinal author's construction of texts. It will also help students strengthen their vocabulary and language use which can also be applied in speaking. Foong (1999) claims that learning to write is important and useful for language and rhetorical practice for communication, and as a discovery as well as cognitive process.

Learning is not separated from learning strategies. It is used to achieve the goals of learning. Learning strategies are the behaviors and thoughts that a learner engages in during learning that are intended to influence the learner's encoding process (Weinstein \& Mayer, 1990). They have learning facilitation as a goal and are intentional on the part of learner. The goal of strategy is to affect the learners' motivational or affective state, or the way, in which the learner selects, acquires, organizes, or integrates new knowledge. The learning strategies are used to make learning easier so the learner can understand the subject easily.

A learning strategy in language learning has been defined as conscious mental activity that containing a goal or intention, an action to 
reach this goal, and a learning activity (Cohen, 2007). Cohen also notes contention among academics over this definition, in that not all learning strategies necessarily reflect these three factors. Self-regulation in language learning refers to the processes the learner uses to exercise control over learning. This term has also caused contention in the field, and some researchers use the term synonymously with autonomy ad self-management (Cohen, 2007). There are obvious connection that link both learning strategies and self-regulation to self-access learning, and tha raising of awareness and knowledge necessary for a learner to exercise responsibility for their learning (White, 2008).

Learning strategies are specific actions taken by the learner to make learning easier, faster, more enjoyable, more self-directed, more effective and more transferable to new situations. In dealing with learning materials and demands during language use, learners will engage in systematic mental steps to process the language in order to entrance production, comprehension, learning or retention (O'Malley \& Chamot, 1990). Strategies also include the tools for the selfdirected involvement of students in their learning which is viewed as necessary for developing their communication skills. Learning strategies are often considered to be the outer layer of the onion, implying that they are most influenced by the environtment and a variety of constructs such as instructional preferences, learning style and cognitive style (Curry, 2002).

A strategy is useful if the following conditions are present: (1) the strategy relates well to the L2 task at hand, (2) the strategy fits the particular student's learning style preferences to one degree or another, and (3) the student employs the strategy effectively and links it with other relevant strategies. Strategies that fulfill these conditions make learning easier, faster, more enjoyable, more self-directed, more effective, and more transferable to new situations (Oxford, 1990).

Learning strategies are different from learning style. Learning styles according to Brown (2000) are general characteristics that differentiate one individual from another; strategies are those specific attacks that we make on a given problem. They are the moment by moment techniqus that we employ to solve the problems posed by second language input and output. Learning strategies are divided into three categories, they are cognitive, metacognitive, and socioaffective strategies. Metacognitive strategies are about planning and evaluating learning, cognitive strategies are about the ability of brain to learn something, and socioaffective strategies are about students' interaction with others.

Learning foreign language is difficult, especially in learning English. Sometimes, students have problems in learning English. Because of it, students use some strategies in learning English. They use these strategies to solve their learning problem. On the other hand, some students also use it to increase their English achievement test scores. From their scores, the students will know ehether they have been successful learners. Observations and research studies led researchers (Rubin, 1975; Stern, 1975; Rubin and Thompson, 1994) to describe good language learners in terms of personal characteristics, styles and strategies. They believe that good language learners:

a. Find their own way, taking responsibility for their own learning

b. Organize information about language

c. Are creative and try to feel the language by experimenting its grammar and words

d. Create opportunities for practice in suing the language inside and outside the classroom

e. Learn to live with uncertainty by not getting confused and by continuing to talk or listen without understanding every word

f. Use memory strategies to bring back what has been learned

g. Make errors work for them and not against them

h. Use linguistic knowledge, including knowledge of the first language, in learning a second language

i. Use contextual cues to help them in comprehension

j. Learn to make intelligent guesses 
k. Learn chunks of language as wholes and formalized routines to help them perform 'beyond their competence'

1. Learn to use certain tricks to keep conversations going

m. Learn certain production strategies to fill in gaps in their own competence

n. Learn different styles of speech and writing and learn to vary their language regarding the formality of the situation

In this study, the writer chooses this topic to know whether there is a correlation between students' learning strategies and their scores in English writing achievement test. Then, from the result of the correlation analysis, it will be known whether or not learning strategies are related to their achievement test scores and whether or not learning strategies are important in learning English.

\section{METHOD}

This study is called a correlational study, because this study seeks to identify the possible relationship between two variables that is learning strategy and students' writing skill achievement. Correlational research refers to studies in which the purpose is to discover the relationship between variables through the use of correlational statistics. A positive correlation indicates that the variables vary together in the same direction, so increases in one variable are equivalent with the other. this study has two variables.

There were 30 students of second semester English Education Department taken as participants. The instruments used in this research were learning strategy questionnaire and students' writing acheievement test. This research has two variables, dependent and independent variable. The independent variable is students learning strategies and the dependent variable is students' writing achievement test scores. For the independent variable, the data was obtained from the result of the learning strategies questionnaires. Meanwhile, for the dependent variable, the data was obtained from the result of writing achievement test.

The data for this study were collected using two instruments. They are learning strategies questionnaire and writing skill achievement test. As the data were in the form of interval scale and because there was always a possibility that the result of the study will show no relationship between the both variables, the Pearson Product Moment Formula was used. The formula is as follows:

$$
\mathrm{r}_{\mathrm{xy}}=\frac{N \sum X Y-\left(\sum X\right)\left(\sum Y\right)}{\sqrt{\left[N \sum X^{2}-\left(\sum X\right)^{2}\right\}\left[N \sum Y^{2}-\left(\sum Y\right)^{2}\right\}}}
$$

\section{RESULTS AND DISCUSSION}

The scores of the questionnaire were obtained by summing up the item credits of the students' answer. Each item had four response options, always credited 3 , often credited 2, sometimes credited 1 , and never credited 0 . From the questionnaire, it shows that the highest score was 46, the lowest score was 30 . Meanwhile, the mean score was 38.83 , the median was 39 , the mode was 38 , and the standard deviation was 3.71. The frequency distribution of the score is presented in Table 1 .

Table 1. The frequency distribution of students'

\begin{tabular}{ccc}
\multicolumn{3}{c}{ learning strategy score } \\
\hline Class Limits & Frequency $\left(\mathrm{f}_{\mathrm{i}}\right)$ & Percentage $(\%)$ \\
\hline $29-31$ & 2 & 6,67 \\
$32-34$ & 2 & 6,67 \\
$35-37$ & 5 & 16,67 \\
$38-40$ & 11 & 36,67 \\
$41-43$ & 8 & 26,67 \\
$44-46$ & 2 & 6,67 \\
Total & 30 & 100 \\
\hline
\end{tabular}

The data of writing ability are collected by using writing test, it shows that the highest score was 85 , the lowest score was 75 . Meanwhile, the mean score was 78.47 , the median was 77.50 , the mode was 76 , and the standard deviation was 2.65 . The frequency distribution of the score is presented in Table 2.

Table 2. The frequency distribution of students' writing ability score

\begin{tabular}{ccc}
\hline Class Limits & Frequency $\left(\mathrm{f}_{\mathrm{i}}\right)$ & Percentage $(\%)$ \\
\hline $74-75$ & 1 & 3,33 \\
$76-77$ & 14 & 46,67 \\
$78-79$ & 4 & 13,33 \\
$80-81$ & 6 & 20,00 \\
$82-83$ & 3 & 10,00 \\
$84-85$ & 2 & 6,67 \\
Total & 30 & 100 \\
\hline
\end{tabular}


Before testing the hypothesis, the writer computed the normality of writing test and learning strategy score. After being computed the writing score, it is known that the value of $\mathrm{L}_{\mathrm{o}}$ ( $\mathrm{L}_{\text {obtained }}$ ) was 0.1429 . Then, the value of $\mathrm{L}_{t}$ ( $\left.\mathrm{L}_{\text {table }}\right)$ for $\mathrm{n}=30$ at the level significance $\alpha=$ 0,05 was 0.1618 . Because the $\mathrm{L}_{\mathrm{o}}(0.1429)$ is lower than $\mathrm{L}_{t}$ ( 0.1618), it can be concluded that the data are in normal distribution. Meanwhile, in learning strategy score, it is known that the value of $\mathrm{L}_{0}$ ( $\mathrm{L}_{\text {obtained}}$ ) was 0.1497. Then, the value of $\mathrm{L}_{t}\left(\mathrm{~L}_{\text {table }}\right)$ for $\mathrm{n}=30$ at the level significance $\alpha=0,05$ was 0.1618 . Because the $\mathrm{L}_{\mathrm{o}}(0.1497)$ is lower than $\mathrm{L}_{\mathrm{t}}$ (0.1618), it can be concluded that the data are in normal distribution.

The writer continue the computation to test the hypothesis of this correlational study by using Pearson Product Moment formula. The correlation analysis shows that the correlation of coefficient $\left(\mathrm{r}_{\mathrm{xy}}\right)$ between students' writing ability (X) and learning strategy (Y) was 0.700 . Then, it is being calculated to the tvalue, the value of $t_{o}$ ( $\left.t_{\text {obtained }}\right)$ was 7.272. The value of $\mathrm{t}_{\mathrm{t}}\left(\mathrm{t}_{\text {table }}\right)$ at the level of significance $\alpha=$ 0,05 was 1.701 . Because $t_{0}$ (7.272) is higher than $t_{t}(1.701)$ or $t_{0}>t_{t}$, it can be said that the coefficient of correlation (r) is significant. In other words, it means that the null hypothesis $\left(\mathrm{H}_{\mathrm{o}}\right)$ is rejected. Therefore, it can be concluded that there is a positive correlation between students' writing ability and learning strategy. The positive correlation between the students' writing will increase or decrease following the students' learning strategy.

After computed the correlation analysis, it was got that there is a positive correlation between learning strategies and writing achievement test score of the second semester students of English Education Department. It is logical to say that learning strategies has a contribution to writing ability. Students who have high score in learning strategy, they will have better writing ability than others. It indicates that learning strategies can influence their achievement test score. The students who got good score cognitive and metacognitive strategies, they also got good score in achievement test. It indicates that cognitive and metacognitive strategies can influence their achievement test score. This is in line with the study of learning strategies in foreign language instruction which has conducted by Chamot (1987). His study is the description of identification of the range and characteristics of learning strategies used in studying foreign language. The result of this study is that the students at all levels of instructions use predominantly cognitive strategies supported by metacognitive strategies.

Learning strategies are used to make learning easier so the learner can understand the subject easily. O'Malley and Chamot (1990) state that learning strategies are specific actions taken by the learner to make learning easier, faster, more enjoyable, more self-directed, more effective and more transferable to new situations. In dealing with learning materials and demands during language use, learners will engage in systematic mental steps to process the language in order to entrance production, comprehension, learning or retention. Learning strategies also used by learners when they face some problems in learning. According to Ellis (2003), learning strategies are the particular approaches or techniques that learners employ to try to learn a second language. They can be behavioral or they can be mental. They are faced with some problems; such as how to remember new word learners are generally aware of the strategies they use and when asked can explain what they did to try to learn something. It means that students use strategies when they face many problems. For example, when they have many difficulties in remembering new words, they use a strategy to make it easier for them.

L2 learning strategies are specific behaviors or thought processes that students use to enhance their own L2 meaning. A given strategy is neither good nor bad, it is essentially neutral until the context of its use is thoroughly considered. Learning strategies can also enable students to become more independent, autonomous, lifelong learners (Allwright, 1990; Little, 1991). Strategy training in the classroom could be used to enhance students' awareness of effective English language learning strategies and their optimal methods of implementation; as a result, students' proficiency levels in English 
could be improved on the whole. Students acquire a better understanding of how to learn when language content is integrated with strategies for learning. As a result, teaching and learning materials will be more retrievable, memorable, and comprehensible for learners.

The finding in the area of language learning strategies have repeatedly demonstrated that the use of language learning strategies leads to better proficiency or achievement in mastering the target language (Lee, 2003; O’Malley \& Chamot, 1990; Rahimi et al., 2008; Griffiths, 2003; Hong, 2006; Oxford, 1993). O’Malley et al., (1985) clearly highlighted the importance of learning strategies by defining them as " any set of operations or steps used by a learner that will facillitate the acquisition, storage, retrieval or use of information". In a study (O'Malley et al., 1985) it has been found that successful language learners have reported to use more and wider range of learning strategies than less-successful students. The same conclusion has been reached in another study (Green \& Oxford, 1995) in which language learning strategies of all kinds were used more frequently by more proficient students. In different study (Griffiths, 2003), a strong positive correlation between learning strategy use and language proficiency has been discovered. The findings revealed that advanced language learners have reported to employ learning strategies more frequently than elementary students.

Dreyer and Oxford (1996) found a very high correlation between language proficiency and strategy use among Afrikans. Proficient learners used the cognitive strategy of using mental processes, the comparison strategy of compensating for missing knowledge, and the metacognitive strategy of organizing and evaluating learning significantly more than less proficient learners. The use of social strategies was more common among the less proficient learners. Park (1997) explored the relationship between strategy use and proficiency in a Korean context and found a significant linear relationship between the two. Besides, Phillips (1991) argues that intermediate learners used more strategies than advanced and low proficiency students indicating a curvilinear relationship between these two variables. There was no clear indication of level of proficiency and individual strategies.

The environtment in which the learner learns does influence how the learner learns a language. Learners desire to learn a language is related to the value attached to learning that language in society

By conducting numerous studies, researchers have discoverd that there is an association between the use and choice of learning strategies and different variables like learning contexts, learner charecteristics and learner experiences, language proficiency, or cultural and educational backgrounds (Oxford, 2003; Khamkhien, 2010; Hong, 2006; Deneme, 2008; Fuping, 2006). Zare (2012) states that the employement of language learning strategies facilitate and improve language learning and assist language learner in different ways. It is also found that a direct correlation exists between language proficiency and language learning achievement (Griffiths, 2003; Yang, 2007; YaLing, 2008). Oxford (1990), learning strategies are oriented towards the main goal of communicative competence, allow learners to get more self-directed, and support learning. Students can learn to use language learning strategies to improve their writing skill achievement.

\section{CONCLUSION}

From the result of this study, the mean or average score of students' writing ability score was 78.47. It was good. It means that the students got good scores. There were 15 students got scores that were under the average and the rest of students got scores that were above the average. Then, the coefficient correlation of the students' learning strategy and their writing achievement test score was 0.700 . It meant that there is a positive correlation between students' learning strategies and their writing achievement test scores because the value of $t_{o}(7.272)$ is higher than $t_{t}(1.701)$.

Therefore, it is recommended that : (1) the teacher should give the direction to improve 
the students' writing ability; (2) the students should increase their English ability not only learning in school but also practicing English everywhere, and enriching their knowledge related to English; and (3) the result of this study can be a reference for other researchers who would like to conduct further research at the same subject.

\section{REFERENCES}

Allwright, D. (1990). Autonomy in language pedagogy: CRILE working paper 6. Centre for research in education. UK: University of Lancaster.

Brown, H. D. (2000). Principles of language learning and teaching. New York: Longman Inc.

Cohen, A. D. (2007). Coming to terms with language learner strategies: Surveying the experts. In D. C. Cohen, \& E. M. Macaro, (Eds.), Language learner strategies. UK: Oxford University Press.

Daud, N. S., \& Kasim, N. L. A. (2007). Second language writing anxiety. Malaysian Journal of ELT Research, 1-9.

Deneme, S. (2008). Language learning strategy preferences of Turkish students. The Journal of Language and Linguistic Studies, 4(2), 83-93.

Dreyer, C., \& Oxford, R. (1996). Learning strategies and other predictors of ESL proficiency among Afrikans-speakers in South Africa. In R. Oxford (Eds.), language learning strategies around the world: cross-cultural perspectives (pp. 61-74). Manoa: University of Hawaii Press.

Ellis, R. (2003). Second language acquisition. Oxford: Oxford University Press.

Foong, K. P. (1999). Teaching writing: A look at purposes, writing tasks, and implication. The English Teacher, 28, 2-5.

Fuping, X. (2006). The impact of strategy training on reading comprehension. CELEA Journal, 29(4), $36-42$.

Green, J. M., \& Oxford, R. L. (1995). A closer look at learning strategies, L2 proficiency, and gender. TESOL Quarterly, 29(2), 261-297.

Griffiths, C. (2003). Patterns of langugae learning strategy use. System, 31, 367-383.

Harmer, J. (2004). How to teach writing. London: Pearson Education Limited.

Harmer, J. (2007). The practice of English language teaching $\left(4^{\text {th }}\right.$ ed.). United States of America: Longman.

Hong, K. (2006). Beliefs about language learning and language learning strategy use in an EFL: A comparison study of monolingual Korean and bilingual Korean-Chinese university students. Unpublished Doctoral Dissertation, University of North Texas.

Kellog, R., \& Whiteford, A. (2009). Training advanced writing skills: The case for deliberate practice. Educational Psychologist, 44, 250-266.
Lee, K. (2003). The relationship of school year, sex, and proficiency on the use of learning strategies in learning English. Asian EFL Journal, 5(4), 1-36.

Little, D. (1991). Learner autonomy 1: Definitions, issues, and problems. Dublin: Authentik National Assessment of Educational Progress.

O’Malley, J. M., Chamot, A. U., Stewner-Manzanares, G., Kupper, L. J., \& Russo, R. P. (1985). Learning strategies used by beginning and intermediate ESL students. Language Learning, 35(1), 21-46.

O’Malley, J. M., \& Chamot, A. U. (1990). Learning strategies and second language acquisition. New York: Cambridge University Press.

Oxford, R. L. (1990). Language learning strategies: What every teacher should know. New York: Newbury House/ Harper \& Row.

Oxford, R. L. (1993). Research on second language learning strategies. Annual Review of Applied Linguistics, 13, 175-187.

Oxford, R. L. (2003). Language learning styles and strategies: An overview. Oxford: GALA.

Park, G. (1997). Language learning strategies and English proficiency in Korean university stuets. Foreign Language Annals, 30(2), 211-221.

Phillips, V. (1991). A look at learner strategy use and ESL proficiency. CATESOL Journal, 57-67.

Powell, P. (2009). Retention and writing instruction: Implication for access and pedagogy. College Composition and Communication, 60, 664-682.

Rahimi, M., Riazi, A., \& Saif, S. (2008). An investigation into the factors affecting the use of language learning strategies by persian EFL learners. CJAL, 11(2), 31-60.

Raimes, A. (1983). Techniques in teaching writing. New York: Oxford University Press.

Ratnasari, D. (2004). Improving students' writing skills by using peer editing strategy in the writing process at the 4th semester of UMM. Unpublished Thesis. Malang: Postgraduate Program of Islamic University of Malang.

Rubin, J. (1975). What the 'good language learner' can teach us. TESOL Quarterly, 9(1), 41-51.

Rubin, J., \& Thompson, I. (1994). How to be a more successful language learner ( $2^{\text {nd }}$ ed.). Boston: Heinle \& Heinle.

Stern, H. H. (1975). What can we learn from the good language learner? Canadian Modern Language Review, 31, 304-318.

Weinstein, C. E., \& Mayer, R. E. (1990). The teaching learning strategies. New York: Macmillan.

White, C. (2008). Language learning strategies in independent language learning: An overiew. In S. Hud, \& T. Lewis (Eds.), Language learning strategies in independent settings (pp. 3-24). Bristol, UK: Multilingual Matters.

Yale, J. B. (2010). The relationship between reading and writing. Retrieved from http://www.k12reader.com/the-relationshipbetween-reading-and-writing. 
Ya-Ling, W. (2008). Language learning strategies used by students at different proficiency levels. The Asian EFL Journal Quarterly, 10(2), 75-95.

Yang, M. N. (2007). Language learning strategies for junior college students $\mathrm{n}$ taiwan: investigating ethnicity and proficiency. The Asian EFL Journal, 9(2), 35-57.

Zare, P. (2012). Language learning strategies among EFL/ESL learners: A review of literature. International Journal of Humanities and Social Science, 2(5), 162-169. 